\begin{tabular}{|c|c|c|}
\hline & International Journal of Current Research in & \\
\hline & Biosciences and Plant Biology & $55^{\circ}=$ \\
\hline $\begin{array}{l}\text { EXCELLENT } \\
\text { PUBLISHERS }\end{array}$ & 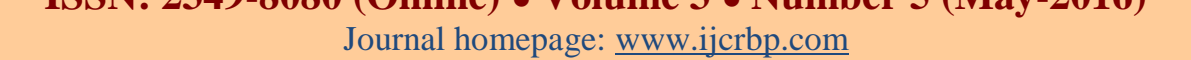 & \\
\hline
\end{tabular}

\title{
Dissemination of Dry Flower Technology for Societal Good
}

\begin{abstract}
Atul Batra*
Sr. Technical Officer, Floriculture Section, CSIR-National Botanical Research Institute, Rana Pratap Marg, Lucknow-226 oo1, Uttar Pradesh, India

*Corresponding author.
\end{abstract}

\begin{abstract}
In floriculture industry and cut flower trade there is always demand of new and novel cultivars of ornamental plants and their value added products. The floriculture basket comprises of flowers (loose and cut), fillers, live plants, seeds, plant propagules, cactus and succulents, house plants, tissue culture raised plant, value added products viz. essential oils and dry flowers. Since the dry flower Industry is growing in a rapid speed and at present contributed about $70 \%$ of the earning of the floriculture produce. In our country dry flower industry comprises of dehydrated flowers, foliage, fruits and seeds. Dehydrated flower and floral craft is used for making various useful products like greeting cards, landscapes, photo frames, table mats, coasters, wall hangings and potpourri items obtained with ethyl acetate extract in both rice and millet flour media (2.29\% and $2.06 \%)$.
\end{abstract}

\section{Article Info}

Accepted: 23 April 2016

Available Online: 06 May 2016

\section{Ke ywords}

Dehydrated flower

Floral craft

Floriculture industry

Value added

\section{Introduction}

Majorities of the population in rural areas of India is farmers and are directly or indirectly dependent upon agriculture for their livelihood. Due to lack of knowledge of the high value cash crops, their methods of preservation and marketing strategies, the condition of the farmers gradually deteriorate day by day. The rate of agricultural production is so low that it is not keeping at pace with the rate of population growth. Thus supply of food is in serious shortage. In the rural areas, preservation of agricultural produce is also one of the central problems. The producer needs to bring their produce to urban areas as their local markets are too small to accommodate all the fresh vegetables and fruits. However, due to lack of transportation infrastructure, this is often difficult and results in high rate of spoilage of products. A large quantity of agro products is also getting wasted every year simply because of the lack of appropriate food conservation technique (Datta, 2007).
Floriculture has become a profitable industry in many parts of the globe. Cut flower is one of the major components of floriculture trade but the shelf life of cut flowers is very limited. Inspite of using best chemicals for improvement of keeping quality and enhancement of vase life, the cut flowers cannot be stored for a longer period of time. Considering this problem, there is an urgent need of supplying the farmers with appropriate technology, for preservation of flower and floral crafts. Dehydration technology is one potential technology.

\section{Materials and methods}

Drying of flowers is a method of preservation of flowers or the method of removing moisture from the flowers. CSIR-National Botanical Research Institute, Lucknow, which is a pioneer institution to carry out the research work on flower dehydration (Datta and Roy, 2011; Radha Rani and Reddy, 2015). Mainly two methods are commercially viable: 


\section{Pressing}

Pressing is a method of preserving plants to use on pictures, stationery, place cards, etc. Most foliage and simple flowers with few petals press very well. Pansies are an excellent flower for pressing at all stages of flower development. Ferns make excellent pressed plants. Leaves and branches with foliage can be pressed to form plant materials with natural curve. Pressing is done by placing plant materials between layers of an absorbent paper material and applying weight or pressure for at least 5 to 10 days or until the plants are dried (Fig. 1). Newspapers, telephone directories, blotter paper, or tissues are good papers to use (Ranjan and Misra, 2002).

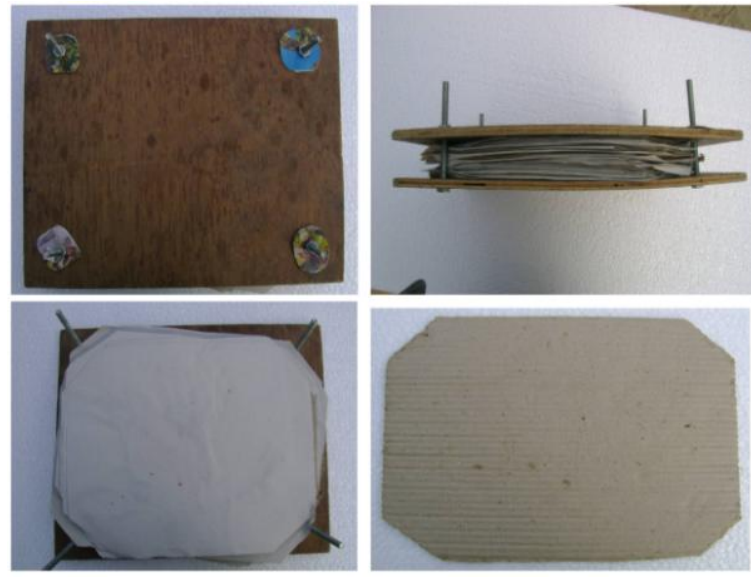

Fig. 1: Materials required for pressing method.

\section{Embedding}

To overcome the problem of petal shrinkage, the flowers were dried by embedding in desiccants viz., borax mixture, fine sand and silica gel. Plastic containers were used for embedding at room temperature in a well-ventilated room. About one inch layer of the desiccant was poured into the bottom of container and the flower stems were pushed into the medium. Desiccant was then gently and gradually poured all around and over the flower up to 4 to $5 \mathrm{~cm}$ above, so as to fill all the crevices in between the petals without disturbing the shape of flowers. After embedding the flowers with desiccants the containers were kept at optimum temperature (Kher and Bhutani, 1979).

\section{Selection of flowers and foliage for dehydration}

Some of the best flowers for dehydration by pressing method are acroclinum, bougainvillea, candytuft, chrysanthemum, dahlia, gerbera, helichrysum, ixoras, marigold, mussaendas, narcissus, nymphaeas, pansy, statice, silver fern, golden fern, grasses, ornamental foliage, etc. and by embedding method are acroclinum, chrysanthemum, candytuft, gerbera, gomphrena, helichrysum, Zinnia linearis, bougainvillea, etc. (Fig. 2).

Drying periods for different flowers (as shown in table below) (Krishna et al., 2012).

\begin{tabular}{lll}
\hline \multirow{2}{*}{ Name of the flower } & Hot Air Oven drying (in hours) \\
\cline { 2 - 3 } & $\mathbf{3 5 - 4 0 ^ { \circ } \mathbf { C }}$ & $\mathbf{4 5 - 5 0 ^ { \circ } \mathbf { C }}$ \\
\hline Acroclinum & - & 48 \\
Bougainvillea & 48 & - \\
Candituft & - & 48 \\
Chrysanthemum & - & $40-45$ \\
Dahlia (pompon) & 72 & - \\
Dombeya & - & 48 \\
Gerbera & & 48 \\
Gomphrena & & 48 \\
Helichrysum & & 48 \\
Ixora & & 24 \\
Marigold (French) & 75 & 72 \\
Marigold (African) & & 72 \\
Narcissus & 60 & 120 \\
Nymphaea & & \\
Pansy & & 48 \\
Statice & & \\
\hline
\end{tabular}




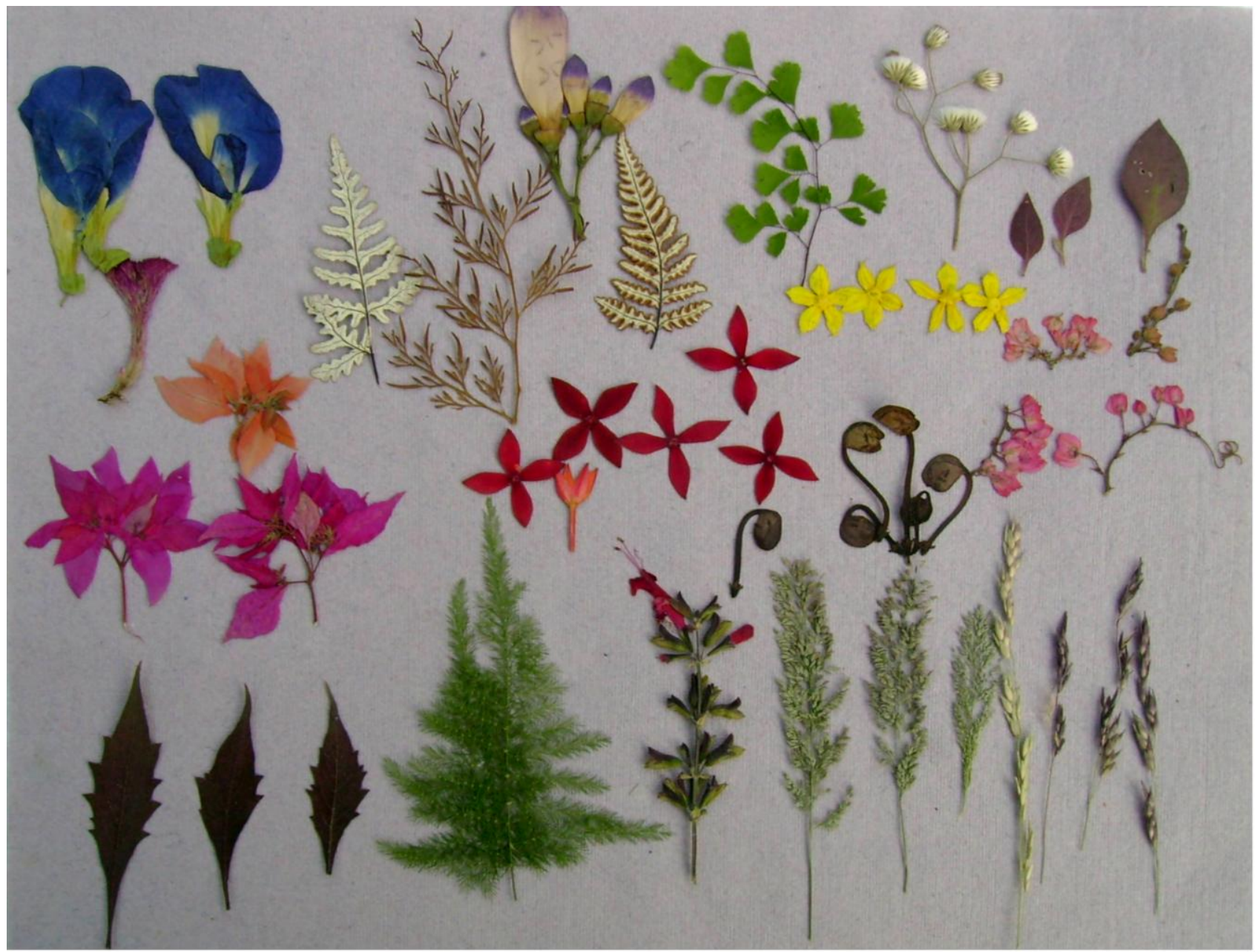

Fig. 2: Dehydrated flowers and foliage.

\section{Tips for quality flower dehydration}

1. Collection of flowers/foliage in dry season.

2. A day or two after irrigating the field.

3. Water droplets on material after harvesting should be absorbed.

4. Selection of fresh materials only.

5. Minimum time gap between plucking and embedding or pressing of plant material.

6. Removal of unwanted portions before embedding/pressing.

7. Materials should be evenly spread in the container.

8. Embedding only one type of flower in one container.

\section{Post dehydration care}

1. Prevention from direct sunlight.

2. Glass containers should be kept in dark and cool place.

3. Pressed flowers are best preserved between folds of blotting papers.

4. Moth Balls should be placed in the storage box.

\section{Uses of dehydrated flower and floral crafts}

The dehydrated flowers retain their original shape, size and colours and can be used in value addition which includes distinctive and artistic greeting cards, landscapes, wall hangings, table mats, Photo frames, paper weights, magnets, decoration of different types and sizes of glass containers, etc. (Fig. 3 and Fig. 4) (Malcolm, 1994). 

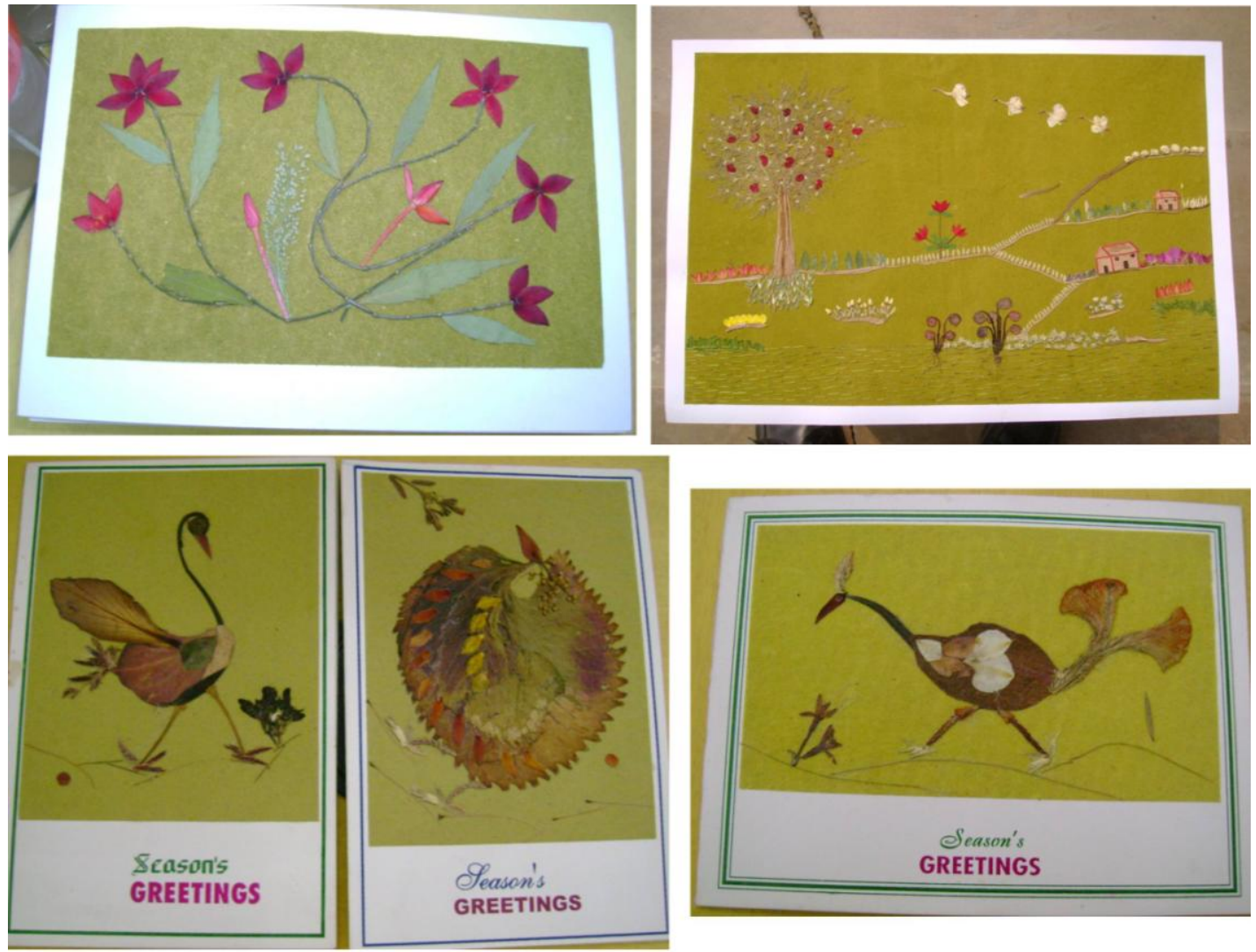

Fig. 3: Greeting cards prepared from dehydrated flowers and foliages.

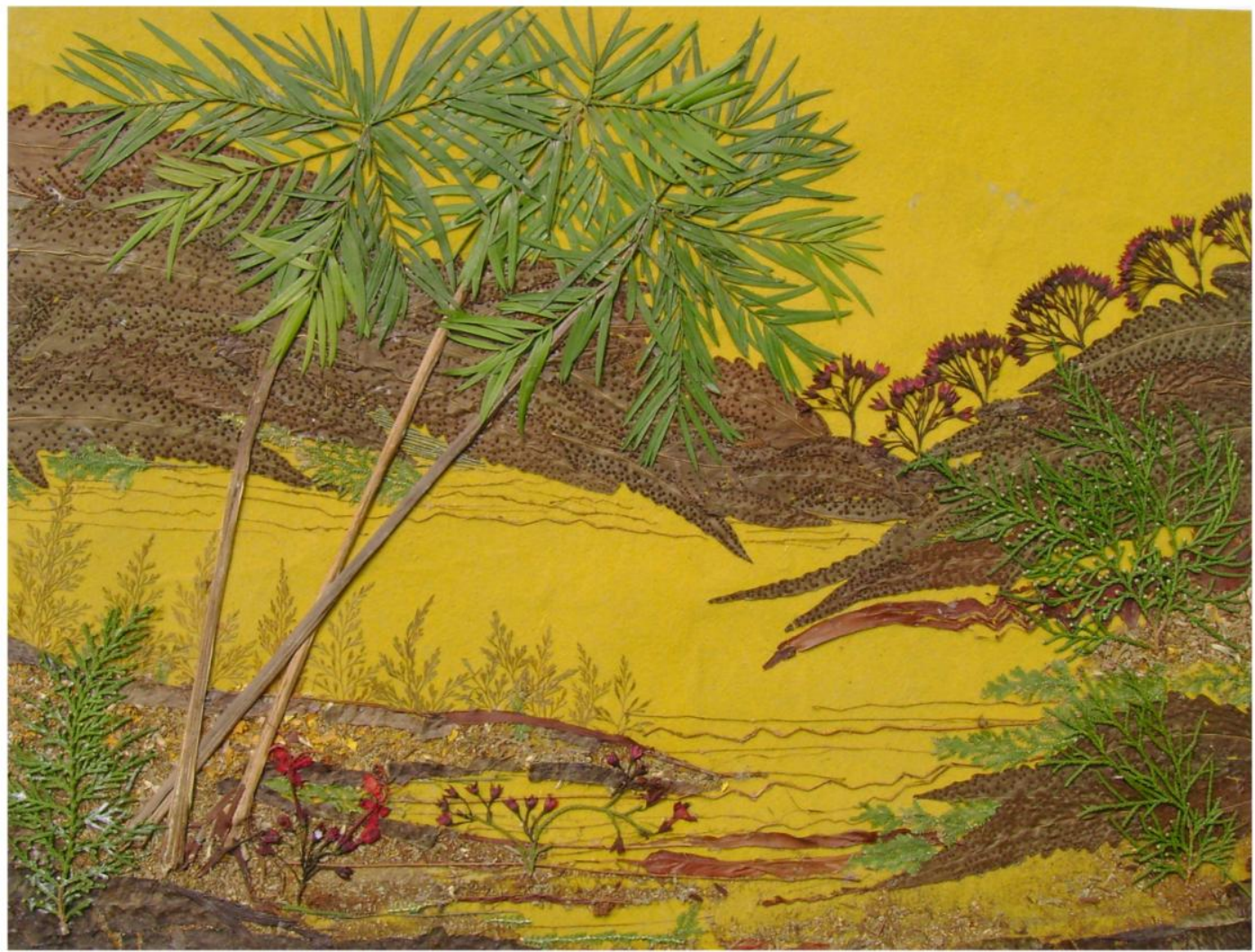

Fig. 4: Landscape prepared from dehydrated flowers and foliages. 


\section{Conclusion}

A small scale industry based on dehydrated floral craft can come up for self employment of youths and for earning money to the house wives as well as rural women by providing them with a part time creative occupation. CSIR - National Botanical Research Institute, Lucknow being a pioneer in dry flower technology has gathered enough expertise with different ornamental plants on this line. Here researchers have standardized the methodology of dehydration by pressing and embedding methods. They have added new dimension to this technology. Many training programmes, awareness camps and exhibition on dehydration of flowers and floral craft have been organized from time to time in different states of our country for unemployed people, rural and urban women, retired persons, students and small farmers to uplift their social and financial status.

\section{Conflict of interest statement}

Authors declare that they have no conflict of interest.

\section{References}

Datta, S. K., 2007. Underutilized and Underexploited Horticultural Crops (Ed.: Peter, K.V.). New India Publishing Agency, New Delhi. pp.159-170.

Datta, S. K., Roy, S., 2011. Employment generation using dehydration technology for drying flowers and foliage and floral craft. Sci. \& Cult. 77(1-2), 58-61.

Kher, M. A., Bhutani, J.C., 1979. Dehydration of flowers and foliage. Extension Bulletin, NBRI, Lucknow. pp.1-20.

Malcolm, H., 1994. Guide to Arranging Dried Flowers. Step by Step Handbook of Growing, Drying and Displaying. Dorling Kindersley Ltd, London.

Radha Rani, P., Reddy, M. V., 2015. Dehydration techniques for flowers. Int. J. Appl. Res. 1(10), 306-311.

Ranjan, J.K., Misra, S., 2002. Dried flowers: a way to enjoy their beauty for a long period. Indian Hort. 46, 32-33.

Tomar, K. S., Kumar, S., Shakywar, R.C., 2012. Flower Dehydration: A Profitable Business for Rural People. College of Horticulture and Forestry, Central Agricultural University, Arunachal Pradesh.

\section{Acknowledgement}

The author is gratefully acknowledging the Director, CSIR-NBRI, Lucknow for providing all the facilities and extending his support to complete this work.

\section{How to cite this article:}

Batra, A., 2016. Dissemination of dry flower technology for societal good. Int. J. Curr. Res. Biosci. Plant Biol. 3(5), 97-101. doi: http://dx.doi.org/10.20546/ijcrbp.2016.305.015 